\title{
ROLE PLAYING: METODE MENUMBUHKAN APRESIASI DRAMA DAN BAHASA ALAMI SISWA
}

\author{
Ria Ariesta, Amril Canrhas, Imranuddin
}

\begin{abstract}
Permasalahan yang dibahas dalam penelitian ini adalah peran metode Role Playing dalam menumbuhkan apresiasi drama dan bahasa alami siswa. Metode penelitian yang digunakan metode deskriptif, dan data dalam penelitian ini merupakan data sekunder, dianalisis secara deskriptif. Hasil analisis menunjukkan bahwa metode Role Playing dapat membantu siswa menumbuhkan apresiasi drama dan bahasa alaminya. Metode ini akan menjadi lebih baik baik lagi jika dilakukan persiapan mengajar dan latiahn penggunaan metode, penggunaan media pembelajaran, memahami gaya belajar dan personalitas pembelajar, dan meningkatkan kualitas peran guru di dalam kelas.
\end{abstract}

Key words: metode role playing, drama

\section{Pendahuluan}

Pengajaran sastra mendapatkan perhatian yang sangat memadai dalam kurikulum tingkat satuan pendidikan (KTSP), ini tampak dari uraian standar kompetensi dan kompetensi dasar. KTSP mata pelajaran Bahasa Indonesia terbagi dalam dua kemampuan, yaitu kemampuan berbahasa dan kemampuan bersastra. Kedua kemampuan ini disajikan dalam empat keterampilan berbahasa, yaitu mendengarkan, berbicara, membaca, dan menulis. Jumlah standar kompetensi dan kompetensi dasar kemampuan bersastra hampir sama dengan kemampuan berbahasa.

Cakupan materi kemampuan bersastra meliputi puisi: menulis puisi, membaca puisi, menanggapi puisi, mendengarkan pembacaan puisi; prosa: menulis dongeng, cerita pendek, esai, resensi novel, membaca dongeng, cerita pendek anak-anak, novel, menceritakan kembali cerita atau dongeng yang pernah didengar, menentukan unsur intrinsik dan ekstrinsik dari cerita atau dongeng yang dibaca; drama mendengarkan pementasan drama, menanggapi pementasan drama, membaca naskah drama, dan menulis drama. Sudah cukup luas dan banyak materi dan alokasi waktu yang diberikan untuk pengajaran dan pembelajaran drama di sekolah.

Tetapi, sayangnya pelaksanaan pengajaran sastra di sekolah belum berubah. Banyak faktor yang menjadi penyebabnya. Pertama, faktor guru (Trianto, 2009). Pada umumnya guru mata pelajaran Bahasa Indonesia kurang tertarik untuk mengajar sastra dengan berbagai alasan. Ini terbukti ketika ada mahasiswa praktikan PPL datang ke sekolah, guru menugaskan mahasiswa untuk mengajar semua kompetensi dasar yang berhubungan dengan sastra. Apalagi dengan kondisi yang ada, sejak penerapan Kurikulum 1994, yaitu urutan penyajian kompetensi dasar diserahkan kepada sekolah. Guru bukan tidak memiliki pengetahuan dan kemampuan mengajar sastra karena mereka pada umumnya sarjana yang telah dibekali ilmu tentang kedua hal tersebut di perguruan tinggi. Ini lebih pada minat dan motivasi guru yang rendah untuk mengajar sastra. Ada juga anggapan 
kalau guru harus menjadi satu-satunya model dalam pembelajaran sastra, padahal model dapat dicari dari kalangan siswa, rekan sesama guru, sastrawan di daerah, atau narasumber lainnya. Kemudian juga keinginan membaca guru yang rendah sehingga karya sastra mutakhir jarang dibahas di sekolah dan guru lebih tergantung pada buku pelajaran di sekolah.

Kedua, pemilihan metode atau strategi mengajar yang tidak bervariasi atau monoton. Pada umumnya pelaksanaan pembelajaran di sekolah menggunakan tahap-tahap sebagai berikut: guru memberikan penjelasan tentang materi yang akan dipelajari, siswa mengerjakan tugas baik secara kelompok atau individual, dan pembahasan secara klasikal. Pelaksanaan pembelajaran ini dilakukan dengan menggunakan metode ceramah, tanya jawab, diskusi kelompok, atau penugasan. Strategi ini dipilih tanpa mempertimbangkan kondisi psikologis siswa, dan waktu/jam pelajaran. Dan, untuk pemelajaran drama strategi pemelajarannya juga sama.

Ketiga, pemilihan sumber belajar. Sumber belajar yang digunakan di sekolah tidak pernah lepas dari buku pelajaran. Buku pelajaran menjadi buku pintar satu-satunya oleh guru di sekolah, ini menyebabkan materi pelajaran menjadi out of date atau kadaluarsa. Bukan berarti bahwa siswa tidak boleh diperkenalkan dengan karya sastra dari sastrawan masa lalu. Tetapi harus ada keseimbangan tentang pengenalan dan pembahasan karya sastra masa lalu dan masa sekarang, yang lebih dekat dengan kehidupan siswa.

Banyak strategi, metode, teknik yang dapat dipilah, dipilih oleh guru untuk pemelajaran sastra, sehingga, dengan begitu mungkin apresiasi siswa terhadap sastra dapat ditumbuhkan. Salah satu metode yang dapat digunakan adalah Role Playing. Berikut akan dibahas pengajaran satra dan bahasa, metode Role Playing, penerapan metode Role Playing dalam pembelajaran drama.

\section{PENGAJARAN BAHASA DAN SASTRA INDONESIA}

Bahasa Indonesia bagi sebagian besar pemelajar Indonesia merupakan bahasa kedua atau bahasa ketiga. Hanya sebagian kecil dari mereka yang bahasa pertamanya bahasa Indonesia, dan biasanya mereka adalah anak-anak yang tinggal di perkotaan dengan orang berpendidikan.

Keadaan ini berpengaruh terhadap pelaksanaan pemelajaran Bahasa Indonesia di sekolah. Ada beberapa prinsip pengajaran bahasa yang harus diperhatikan, yaitu:

1. Melaksanakan penyiapan awal bagi para pembelajar dalam hal melatih kemampuan bahasa spontannya untuk mengasimilasi bahasa lisan yang dipelajari.

2. Melaksanakan pembentukan kebiasaan-kebiasaan baru secara tepat dengan memanfaatkan kebiasaan-kebiasaan yang telah dimiliki sebelumnya.

3. Melaksanakan latihan-latihan dengan cermat untuk menghindari terjadinya pembentukan kebiasaan-kebiasaan yang buruk.

4. Melaksanakan penjenjangan, penahapan, dan pembobotan kegiatan sedemikian sehingga dapat menghasilkan kemajuan yang terus meningkat. 
5. Memberikan proporsi pelatihan yang berimbang dalam berbagai aspek dan cabang-cabang dari bahan ajar.

6. Mengutamakan presentasi bahan bahasa yang konkret dan sedapat mungkin menjauhi yang bersifat abstrak.

7. Memastikan adanya dan menjaga minat pembelajar agar dapat mempercepat kemajuan belajamya.

8. Memegang urutan pertumbuhan kemajuan yang sesuai dengan prinsip-prinsip psikologi percakapan.

9. Menggunakan berbagai pendekatan terhadap materi pembelajaran secara simultan yang diambil dari berbagai sisi secara tepat (Palmer, 1974: 177).

Kesembilan prinsip tersebut secara implisit menuntut guru untuk mengetahui antara lain: gaya belajar, gaya mengajar, berbagai pendekatan, metode, dan teknik mengajar serta implementasinya. Gaya belajar berdasarkan modalitas terbagi empat, yaitu auditorial, visual, membaca, dan kinestetik. Menurut DePorter dan Hernacki (2010: 159) gaya belajar membaca termasuk dalam gaya auditorial. Gaya belajar ini penting untuk diketahui karena akan berdampak pada terjadi atau tidaknya proses belajar dalam diri pembelajar.

Gaya mengajar merupakan sebuah pertimbangan afektif dalam perkembangan keahlian profesional seorang guru. Gaya mengajar selalu konsisten dengan kepribadian atau personalitas seorang guru yang dapat memengaruhi individu ke individu. Menurut Brown (2007: 251) ada beberapa gaya mengajar, yaitu "shygregarious, formal-informal, reservedopened, transparent, understateddramatic, steady-moody, restrictive- permisive serious-humorous, rationalemotional."

Di dalam mengajar guru harus lebih cermat dalam berkata-kata karena setiap perkataan akan menimbulkan asosiasi spesifik. Setiap interaksi yang dilakukan di kelas, cara menyampaikan sesuatu sama pentingnya dengan perkataan , bahkan mungkin lebih penting. Ketika mengajar, memberikan petunjuk, menata konteks, atau memberikan umpan balik, ada empat prinsip yang harus diperhatikan, yaitu memunculkan kesan, mengarahkan fokus, bersifat mengajak (inklusif), bersifat tepat sasaran (spesifik) (DePorter, Reardon, dan Singer-Nourie, 2010: 112).

Paradigma pembelajaran bahasa terus diperbaharui sejalan dengan adanya temuan-temuan baru dalam bidang ilmu pengetahuan yang berkaitan. Hal tersebut memunculkan beragam pendekatan, metode, dan teknik pembelajaran sebagai bentuk inovasi dalam bidang pendidikan. Pendekatan pembelajaran menentukan keberhasilan proses kegiatan pembelajaran serta menunjang pencapaian tujuan pembelajaran (Ridwan, 2011:1). Terdapat berbagai model, dan metode yang telah dikembangkan maupun diadaptasi untuk pembelajaran bahasa Indonesia di sekolah, di antaranya Role Playing.

\section{TUJUAN PENGAJARAN BAHASA DAN SASTRA}

Tujuan pengajaran Bahasa dan Sastra Indonesia dalam pendidikan formal adalah:

1. Siswa menghargai dan membanggakan Bahasa Indonesia 
sebagai bahasa persatuan (nasional) dan bahasa negara.

2. Siswa memahami Bahasa Indonesia dari segi bentuk, makna, dan fungsi,serta menggunakannya dengan tepat dan kreatif untuk bermacam-macam tujuan, keperluan, dan keadaan.

3. Siswa memiliki kemampuan menggunakan Bahasa Indonesia untuk meningkatkan kemampuan intelektual, kematangan emosional,dan kematangan sosial.

4. Siswa memiliki disiplin dalam berpikir dan berbahasa (berbicara dan menulis).

5. Siswa mampu menikmati dan memanfaatkan karya sastra untuk mengembangkan kepribadian, memperluas wawasan kehidupan, serta meningkatkan pengetahuan dan kemampuan berbahasa.

6. Siswa menghargai dan membanggakan sastra Indonesia sebagai khazanah budaya dan intelektual manusia Indonesia (Fadlan,2010).

Tampak jelas bahwa tujuan pengajaran bahasa Indonesia juga termasuk di dalamnya pengajaran sastra. Lebih jauh menurut Moody yang ditegaskan kembali oleh Waluyo tujuan pembelajaran sastra dapat dibagi menjadi empat, yaitu informasi, konsep, perspektif, dan apresiasi. Pertama informasi, yaitu tujuan yang berkaitan dengan pemahaman pengetahuan dasar tentang sastra. Kedua, konsep, yaitu tujuan yang berkaitan dengan pemahaman terhadap pengertianpengertian pokok mengenai suatu hal. Ketiga, perspektif, yaitu tujuan yang berkaitan dengan kemampuan untuk memandang bagaimana sebuah karya sastra itu diciptakan menurut perspektif pikiran siswa. Keempat, apresiasi, yaitu tujuan yang berkaitan dengan pemahaman, penghayatan, penikmatan, dan penghargaan siswa terhadap karya sastra.

Apresiasi menurut Waluyo (2003) terbagi dalam empat tingkatan, yaitu tingkat menggemari, tingkat menikmati, tingkat mereaksi, tingkat produktif. Sedangkan, tahapan dalam melaksanakan apresiasi drama menurut Nurhadi adalah: pahami sinopsis drama yang dimainkan (jika ada), pahami karakter tiap pemain, perhatikan alur cerita, analisis pemain utamanya, tentukan konflik yang muncul dari dialog antartokoh untuk menentukan amanat, perhatikan dialog antartokoh, perhatikan dubbing audio dengan gerakan pemain, beri komentar terhadap pementasan.

\section{ROLE PLAYING (BERMAIN PERAN)}

Guru yang kreatif akan senantiasa mencari pendekatan, metode, dan teknik baru dalam pemecahan masalah pengajaran dan pembelajaran bahasa. Guru tidak hanya terpaku pada satu metode tertentu sehingga pembelajaran berjalan dengan monoton. Variasi pendekatan, metode, dan teknik dapat membangkitkan motivasi siswa belajar di kelas dan luar kelas. Bermain peran merupakan salah satu alternative metode dalam pengajaran bahasa Indonesia yang dapat menumbuhkan apresiasi drama dan memunculkan bahasa alami siswa.

Secara sederhana, bermain peran merupakan usaha untuk memecahkan masalah melalui peragaan tindakan. Peran dapat didefinisikan sebagai suatu rangkaian perasaan, ucapan, dan tindakan. Peran merupakan suatu pola 
hubungan unik dan membiasa yang ditunjukkan seorang individu kepada individu lain, yang dipengaruhi oleh persepsi individu itu terhadap dirinya dan individu lain.

Adapun asumsi yang mendasari metode ini adalah:

1. Menitikberatkan dimensi di sini dan kini sebagai isi pengajaran

2. Memberikan kesempatan pada siswa untuk mengungkapkan perasaan yang tidak dapat dikenali tanpa becermin pada orang lain

3. Emosi dan ide-ide dapat diangkat ke taraf kesadaran untuk kemudian ditingkatkan melalui proses kelompok

4. Proses-proses psikologis yang tersembunyi berupa sikap, nilai, perasaan, dan system keyakinan dapat diangkat ke taraf kesadaran melalui kombinasi pemerananan secara spontan

Manfaat metode ini tergantung pada tiga hal, yaitu: (1) kualitas pemeranan, (2) analisis yang dilakukan melalui diskusi usai pemeranan, dan (3) persepsi siswa terhadap peran yang ditampilkan dibandingkan dengan situasi kehidupan nyata (Dahlan, Ed., 1984: 124127).

Menurut Shaftel dan Shaftel (Joyce dan Wall, 1980: 247) ada sembilan tahap metode bermain peran, yaitu:

1. Tahap 1: memotivasi kelompok dengan langkah-langkah, mengidentifikasi masalah, menjelaskan masalah, menginterpretasi cerita, mengeksplorasi isu, (4) menjelaskan peran yang akan dimainkan.

2. Tahap 2: memilih pemeran, langkahlangkah, (1) menganalisi peran, (2) memilih dan menetapkan pemeran.
3. Tahap 3: menyiapkan pengamat, langkah-langkah, (1) memutuskan apa yang akan dan perlu diamati, (2) menjelaskan tugas-tugas pengamat.

4. Tahap 4; menyiapkan tahap-tahap peran, langkah-langkah,

memerinci urutan peran, menjelaskan kembali peran yang akan dimainkan, (3) memasuki situasi masalah,

5. Tahap 5: pemeranan, langkahlangkah, (1)memulai bermain peran, (2) meneruskan pemeranan, menghentikan pemeranan.

6. Tahap 6: diskusi dan evaluasi 1, langkah-langkah, (1) mengkaji ketepatan pemeranan, mendiskusikan focus utama, (3) mengembangkan pemeranan ulang.

7. Tahap 7: pemeranan ulang, langkahlangkah, (1) memainkan peran yang perlu diperbaiki, (2) mengemukakan alternativif perilaku selanjutnya yang mungkin muncul dari pemeranan ulang.

8. Tahap 8: diskusi dan evaluasi, langkah seperti pada tahap 6 .

9. Tahap 9: membagi pengalaman dan menarik generalisasi, langkahlangkah, (1) menghubungkan situasi masalah dengan pengalaman nyata dan masalah-masalah yang sedang berlangsung, (2) mengeksplorasi prinsip umum tentang perilaku.

Ada lima prinsip reaksi yang harus diperhatikan guru dalam bermain peran, yaitu: (1) guru menerima respons yang ditunjukkan siswa tanpa memberikan penilaian, (2) membantu siswa mengeksplorasi situasi dari berbagai sudut, (3) meningkatkan kesadaran siswa akan pandangan dan perasaannya sendiri melalui kegiatan refleksi, (4) menekankan pada siswa tentang 
berbagai cara untuk memainkan suatu peran, setiap cara memiliki konsekuensi, (5)menekankan pada siswa ada berbagai kemungkinan cara untuk memecahkan masalah, tidak ada satu cara pun yang paling tepat (Joyce dan Wall, 1980:.138).

\section{Hasil Dan Pembahasan}

Metode Role Playing ini diterapkan dalam pembelajaran Bahasa Indonesia dengan kompetensi dasar "Mengekspresikan dialog para tokoh dalam pementasan drama" pada siswa kelas XI IPA 4 semester 2 di SMAN 7 Plus Kota Bengkulu tahun pelajaran 2010/2011, dengan jenis penelitian tindakan kelas (PTK). Penelitian dilakukan dalam dua siklus, empat kali pertemuan atau $8 \times 45$ menit. Aspek yang dinilai adalah 1) kemampuan mengungkapkan perasaan,

kemampuan memerankan tokoh sesuai dengan karakternya, 3) kemampuan menggunakan intonasi dan lafal yang tepat, 4)) kemampuan mimikri, 5)) kemampuan gerak gerik tokoh yang sesuai. Kesimpulan penelitian menunjukkan bahwa terdapat peningkatan hasil belajar drama dengan menggunakan metode Role Playing dengan peningkatan skor sebesar 5,062. Pada siklus 1 terdapat enam orang siswa yang belum mencapai nilai ketuntasan belajar (KKM) karena dalam pemeranan suara mereka tidak terdengar dan gerakgerik mereka kaku. Pada siklus ini suasana kelas ribut disebabkan siswa tidak mengerti apa yang harus dilakukan, penjelasan guru tidak dipahami. Siswa. Tetapi, pada siklus 2 semua siswa telah mencapai KKM dan mampu memerankan peran yang diberikan kepada mereka. Para siswa bukan hanya dapat berekspresi dengan baik, tetapi juga dapat melakukan dialog tanpa menggunakan naskah. Dengan kata lain, pemeranan dikembangkan melalui improvisasi di antara pembelajar, yang memungkinkan untuk menumbuhkan bahasa alami siswa (Suheri, 2011).

Walaupun kegiatan penelitian ini sudah dilakukan dan menunjukkan peningkatan dalam hasil belajar, tetapi masih terdapat berbagai keterbatasan yang masih dapat diatasi sehingga untuk penelitian berikutnya dengan menggunakan metode ini hasil yang diperoleh bisa lebih baik lagi.

1. Persiapan mengajar dan latihan penggunaan metode: Karena metode ini belum pernah diterapkan oleh guru di dalam kelasnya seharusnya persiapan yang dilakukan disertai dengan latihan menggunakan metode. Guru dapat mengantisipasi dan mengidentifikasi masalahmasalah apa yang ada di sekitar siswa atau yang sedang mereka hadapi sehingga dalam praktiknya akan berjalan lancar dan tidak menghabiskan waktu.

2. Penggunaan media pembelajaran: Fokus perhatian guru bukan tertumpu pada metode saja karena penerapan metode tersebut tujuannya adalah membantu siswa untuk mencapai tujuan sehingga kompetensi dikuasainya. Ada baiknya dipersiapkan media audiovisual untuk memberikan contoh kepada siswa cara berperan yang baik, yang diberikan di awal pembelajaran untuk membantu siswa mengatahui cara menghayati peran dan memerankannya.

3. Memahami gaya belajar dan personalitas pembelajar: Penggunaan media dan aktivitas yang bervariasi 
dapat mengakomodasi kebutuhan belajar siswa. Dalam penelitian masih terdapat siswa yang belum mampu berbicara dengan suara keras di depan kelas. Ada beberapa penyebab, selain siswa tidak paham dengan instruksi dan pengarahan guru, antara lain siswa takut bahasa yang diucapkannya tidak diterima oleh orang lain karena yang terjadi selama ini adalah bukan hanya sesama siswa yang menertawakan jika mereka salah dalam berbahasa, tetapi guru juga ikut menertawakan. Ini berakibat kegiatan eksplorasi perasaan melalui kegiatan berbahasa terhambat. Siswa yang tertutup (introvert) akan semakin menutup diri dengan kondisi yang seperti ini. Sehingga, bahasa alami tidak dapat dikembangkan

4. Meningkatkan kualitas peran guru di dalam kelas: Selama proses belajar mengajar, pada umumnya, guru seperti "robot" menjalankan skenario tanpa melibatkan emosi positif di dalamnya.

Penguatan

(reinforcement) yang diberikan oleh guru pun monoton sehingga tidak bermakna bagi peningkatan motivasi belajar siswa. Dalam pembelajaran drama, keterampilan yang dituntut bukan hanya keterampilan verbal tetapi juga keterampilan nonverbal. Agar apresiasi drama dan bahasa alami siswa dapat tumbuh dan dikembangkan melalui metode ini kualitas peran guru sebagai motivator, fasilitator, dan mediator harus selalu diperhatikan,

\section{Simpulan}

Metode Role Playing adalah metode yang awalnya digunakan bukan untuk bidang pengajaran, apalagi pengajaran bahasa, seperti metode Audiolingual. Tetapi, seiring dengan tuntutan kebutuhan dan perkembangan ilmu pengetahuan dan teknologi, melalui berbagai adaptasi dan uji coba metode ini dapat diterapkan dalam pembelajaran bahasa, khususnya Bahasa Indonesia. Kreativitas guru sangat dituntut di dalam menerapkan sebuah metode karena penerapannya tergantung pada karakteristik siswa dan situasi dan kondisi kelas. Guru jangan hanya berpatokan pada langkah-langkah yang sudah ditetapkan, tetapi juga harus mampu melakukan improvisasi sehingga dapat menciptakan suasana kelas yang nyaman dan menyenangkan sehingga tujuan pembelajaran tercapai dan kompetensi dikuasai siswa.

\section{Daftar Pustaka}

Brown, H. Douglas. 2007. Teaching by Principles. New York: Pearson Education..

Dahlan, M.D. 1984. Model-model Mengajar. Bandung: CV Diponegoro,

DePorter, Bobbi dan Mike Hernacki. 2010. Quantum Learning. Penerjemah Alwiyah Abdurrahman, Bandung: Kaifa.

DePorter, Bobbi, Mark Reardon, Susan Singer-Nourie, 2010. Quantum Teaching. Penerjemah Ary Nilandari, Bandung: Kaifa.

Fadlan, M. Nida. 2010. http://miftah19. wordpress.com/2010/09/27/tuju an-pembelajaran-bahasa/ 
http://id.shvoong.com/socialsciences/education/2120528tujuan-pembelajaran-sastramenurut-moody/

Joyce, Bruce dan Marsha Weil. 1980. Models of Teaching, New Jersey: Prentice-Hall.

Palmer, H.E. 1974. The Principles of Language Study. Oxford: Oxford University Press

Ridwan, Sakura. 2011. Metodologi Pemelajaran Bahasa: Aplikasi dalam Pengajaran MorfologiSintaksis, Yogyakarta: Kepel Press.
Suheri, Anita. 2011. "Penerapan Model Pembelajaran Role Playing untuk Meningkatkan Kemampuan Apresiasi Drama Siswa Kelas XI IPA 4 SMA Plus Negeri 7 Kota Bengkulu Tahun pelajaran 2010/1011", Skripsi, Bengkulu: Tidak Diterbitkan.

Trianto, Agus. 2009, "Problem Pengajaran Sastra di SMK" http://agupenajateng.net/2009/0 $2 / 20$ /problem-pengajaran-sastradi-smk

Waluyo, Herman J. 2003. Drama: Teori dan Pengajarannya. Yogyakarta: Hanindita Graha Widya. 